\title{
絭 \\ GEOGRAFIA, TURISMO, RELIGIÃO E RELAÇÕES INTERNACIONAIS: UMA INTRODUÇÃO ACERCA DAS INTERFACES TEÓRICAS
}

\section{ALBERTO PEREIRA DOS SANTOS ${ }^{1}$}

Resumo: Este trabalho enceta um diálogo introdutório acerca das interfaces teóricas entre Geografia, Turismo, Religião e Relações Internacionais. Considerando a Geografia como o ponto de partida para esta reflexão, nosso objetivo é demonstrar, sucintamente, que o turismo e a religião se constituem como temas que interpenetram as relações internacionais: o turismo como instrumento de diplomacia cultural ou soft power no contexto de globalização com o avanço das tecnologias de comunicação e dos meios de transportes no processo de "aceleração do tempo $e$ compressão do espaço" (HARVEY, 1993) e a religião no contexto pós-Guerra Fria com a ascensão das novas geopolíticas e a valorização das culturas, das civilizações e dos grupos étnico-religiosos como atores que interferem nas relações de poder no espaço mundial (VESENTINI, 2000). Busca-se demonstrar também que os quatro temas do titulo deste trabalho suscitam congruências pertinentes à reflexão teórica que privilegia as relações entre Espaço e Cultura.

Palavras-chave: geografia; turismo; religião; relações internacionais; cultura. 


\section{Introdução}

A Geografia, como ciência humana e social, é nosso ponto de partida para esta reflexão que tem como objetivo central demonstrar, sucintamente, que turismo, religião e relações internacionais são temas que se complementam ou se imbricam no espaço geográfico, especialmente numa abordagem teórica que privilegia as relações entre espaço $e$ cultura.

A cultura, ou as culturas, se constitui como a argamassa do espaço geográfico. Alguns poucos geógrafos brasileiros estudam mais especialmente as relações entre espaço e cultura. Nessa perspectiva, pelo menos desde o final da década de 1980, se destaca a rica produção da chamada Geografia Cultural especialmente a partir dos trabalhos pioneiros da geógrafa Zeny Rosendahl e do geógrafo Roberto Lobato Corrêa (ROSENDAHL \& CORRÊA, 2003; 2012, 2013).

Delimitando o recorte teórico, entendemos que as abordagens acerca das relações entre espaço e cultura permitem múltiplos olhares, no espaço e no tempo, conforme as perspectivas, os contextos históricos e, especialmente, de acordo com perspectivas ontológicas e escolhas epistemológicas dos geógrafos, antropológicos, sociólogos e outros especialistas. Entretanto, ancorado, em parte, na teoria da complexidade, ou no chamado pensamento complexo (MORIN, 2005), entendemos também que os múltiplos olhares e análises teóricas acerca das relações entre espaço e cultura não se excluem, ao contrário, se complementam.

0 que se entende por complexidade? Nas palavras de Morin (2005, p. 38):

"O conhecimento pertinente deve enfrentar a complexidade. Complexus significa o que foi tecido junto; de fato, há complexidade quando elementos diferentes são inseparáveis constitutivos do todo (como o econômico, o político, o sociológico, o psicológico, o afetivo, o mitológico), e há um tecido interdependente, interativo e inter-retroativo entre o objeto de conhecimento e seu contexto, as partes e o todo, o todo e as partes, as partes entre si. Por isso, a complexidade é a união entre a unidade e a multiplicidade. Os desenvolvimentos próprios a nossa era planetária nos confrontam cada vez mais e de maneira cada vez mais inelutável com os desafios da complexidade."

Nossa opção teórica neste trabalho, portanto, parte do pressuposto que os múltiplos elementos da cultura como o simbólico, o econômico, o político, o psicológico e outros se imbricam no espaço. Assim sendo, entendemos que a geografia é fundamental para articular as interfaces entre turismo, religião e relações internacionais.

Desde sua gênese, no século XIX, 
a partir do pensamento do geógrafo alemão Friedrich Ratzel, a Geografia esteve vinculada ao poder, ao território, ao Estado, como revela a história do pensamento geográfico (MORAES, 1987). Nesse sentido, os estudos das relações de poder interestatais se vinculam à Geografia, especialmente na geopolítica entendida como campo de estudo interdisciplinar. Assim sendo, o estudo das relações internacionais se constituem como elemento essencial para a geografia e para a geopolítica (VESENTINI, 2003).

Cabe, nesta introdução, sublinhar que as teorias de Relações Internacionais (RI) admitem vários paradigmas como o realismo, o idealismo, o marxismo, o feminismo, entre outros olhares. No tocante à epistemologia o objetivo central das RI é pesquisar as causas das guerras e procurar alternativas ou propostas que promovam a paz mundial. Dois conceitos básicos nas teorias de $\mathrm{Ri}$ merecem destaque, Hard Power e Soft Power: o primeiro, o poder duro, aplicado em casos de guerras militares; o segundo, o poder brando, aplicado em casos de "guerras simbólicas". De um lado, a religião tem sido utilizada como soft power e, de outro, o turismo, por complementaridade, se constitui como forte instrumento de diplomacia cultural nas relações internacionais. Destaca-se que o poder brando, o soft power, é tão poderoso quanto ou talvez até mais poderoso que o poder bruto ou hard power (NEY, 2002).

Partindo do empírico, à guisa de exemplificação, a JMJ Rio 2013 - Jornada Mundial da Juventude - evento de cunho religioso turístico internacional realizado na cidade do Rio de Janeiro, permite-nos refletir a respeito das interfaces entre geografia, turismo, religião e relações internacionais. Nesse caso, o Vaticano é um Estado soberano com direito de observador permanente na ONU (Organização das Nações Unidas) e, por outro lado, representa a sede da Igreja Católica Apostólica Romana, portando o articulador do catolicismo no campo das relações internacionais. No referido megaevento religioso turístico internacional, a JMJ Rio 2013, cerca de dois milhões de peregrinos de diversas nacionalidades cruzaram as fronteiras nacionais de seus países com destino turístico ao Rio de Janeiro.

Nessa

perspectiva, consideraremos a JMJ Rio 2013 megaevento religioso turístico internacional - como exemplo empírico para o desenvolvimento desta reflexão, isto é, uma introdução teórica acerca das interfaces entre geografia, turismo, religião e relação internacionais.

No tocante à metodologia deste trabalho ressaltamos que se trata de uma sucinta revisão bibliográfica que busca dialogar, a partir da Geografia, com alguns autores clássicos das teorias de Relações Internacionais.

Este trabalho está organizado em três partes complementares, a saber: a) Enveredando pela transdisciplinaridade do conhecimento; b) A JMJ Rio 2013 - um megaevento religioso turístico internacional; c) Relações Internacionais, crise de paradigmas e religião; d) Transcendência e Religião nas relações internacionais.

$\mathrm{Na}$ primeira parte, busca-se sucintamente apresentar o conceito de 
transdisciplinaridade como possibilidade para entender e tentar explicitar o pensamento complexo acerca das interfaces teóricas deste trabalho. $\mathrm{Na}$ segunda parte, caracterizamos o que é a JMJ Rio 2013, como exemplificação do empírico, da realidade complexa do objeto que se constitui, ao mesmo tempo, como geográfico, turístico, religioso e internacional. Na terceira parte, busca-se demonstrar que o campo de estudo ou das teorias de RI passa por crise de paradigmas, ou de modelo, de explicação consistente e coerente neste século XX, especialmente a partir do fim da Guerra Fria com desmoronamento do antigo "bloco comunista" e, de modo geral, para os especialistas em RI, a inesperada ascensão do islamismo e a valorização das religiões no mundo atual. Por fim, na quarta parte, busca-se explicitar a ideia de que o tema religião é pertinente no estudo das relações internacionais, uma vez que as religiões, a exemplo do catolicismo e do islamismo, interferem na balança de poder mundial e/ou nas relações internacionais.

Em nossas considerações finais apresentaremos nossa síntese e sinalizando para o caminho que, a nosso ver, se abre a partir da geografia para o estudo transdisciplinar das interfaces entre turismo, religião e relações internacionais, numa abordagem que privilegia as relações entre espaço $e$ cultura.

\section{Enveredando pela}

\section{transdisciplinaridade do conhecimento}

O conhecimento científico, tal como

o conhecemos na atualidade, de modo geral, é resultado do processo disciplinar, isto é, da construção do conhecimento de modo especializado. Não se deve desvalorizar o que foi criado pelas disciplinas, não se pode quebrar todas as clausuras, uma vez que cada disciplina científica historicamente, até pela exigência da cientificidade, delimitou seu objeto de estudo, seus conceitos e bases epistemológicas.

Entretanto, não se pode negar que embora exista semelhança entre o proprietário de terra e o especialista, ambos cuidando de sua fronteira - a da propriedade territorial e a do conhecimento - vez por outra surgem na história alguns indivíduos que rompem certas fronteiras e criam novos caminhos.

Nesse sentido, há que se admitir que o conhecimento científico Ocidental, pelo menos desde o século XVII, não foi apenas um conhecimento disciplinar, mas também um desenvolvimento transdisciplinar. Como afirma Morin (2005a, p.52), "a ciência nunca teria sido ciência se não tivesse sido transdisciplinar".

0 que se entende por transdisciplinaridade? Nas palavras de Morin (2005a, p.51):

"A transdisciplinaridade se caracteriza geralmente por esquemas cognitivos que atravessam as dsicplinas, por vezes com uma tal virulência que as coloca em transe. Em resumo, são as redes complexas de inter, poli e transdisciplinaridade que operaram e desempenharam um 
papel fecundo na história das ciências."

Por sua vez a interdisciplinaridade admite os limites de cada disciplina e de seus especialistas, embora, às vezes, ocasionem trocas, cooperação entre elas e seus especialistas. Nessa concepção, os especialistas entendem que seus saberes são muito importantes para se analisar um determinado fenômeno, entretanto, sabem que seus saberes são limitados. Por isso, a interdisciplinaridade seria o encontro de vários especialistas para discutir e/ou resolver um problema complexo que nenhuma disciplina, sozinha, poderia explicar, compreender e resolver tal problema.

52):

Nas palavras de Morin (2005a, p.

"A interdisciplinaridade controla tanto as disciplinas como a $\mathrm{ONU}$ controla as nações. Cada uma disciplina pretende primeiro fazer reconhecer a sua soberania territorial e, desse modo, confirmar as fronteiras em vez de desmoroná-las, mesmo que algumas trocas incipientes se efetivem."

Abaixo colocamos algumas figuras para ilustrar a relação interdisciplinar entre três campos disciplinares, a saber: Turismo, Relações Internacionais e Geografia.

Tomando como exemplo o fenômeno dos eventos e viagens nacionais e internacionais, sabemos pode ser estudado a partir de múltiplos olhares, não apenas pelo especialista em Turismo.

0 mesmo fenômeno de eventos e viagens nacionais e internacionais pode ser analisado pelo especialista em Relações Internacionais, embora a abordagem seja diferente do especialista em Turismo. Por exemplo, em RI a viagem implica em detalhes específicos da diplomacia (passaporte, direito internacional, etc).

Por sua vez, o mesmo fenômeno de eventos e viagens nacionais $e$

Turismo e interdisciplinaridade

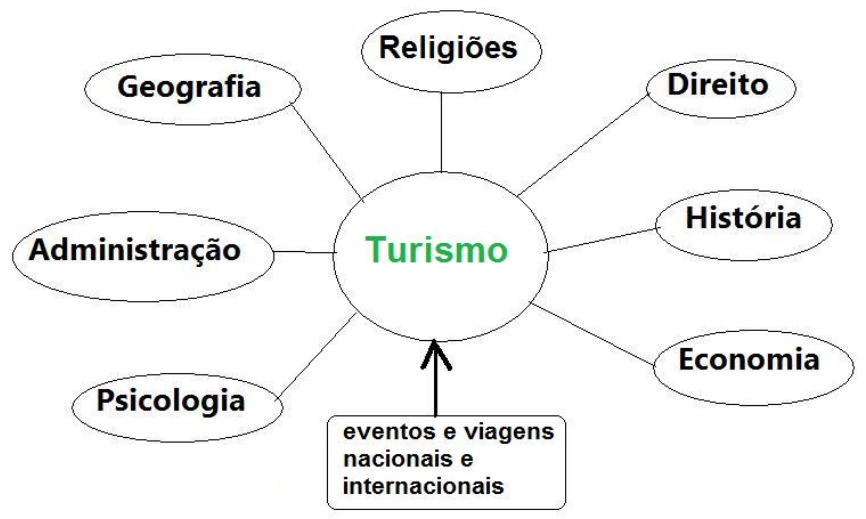

Elab: SANTOS, A.P.

ESPAÇO E CULTURA, UERJ, RJ, N. 35, P.125-151, JAN./JUN. DE 2014

http://www.e-publicacoes.uerj.br/index.php/espacoecultura/ 


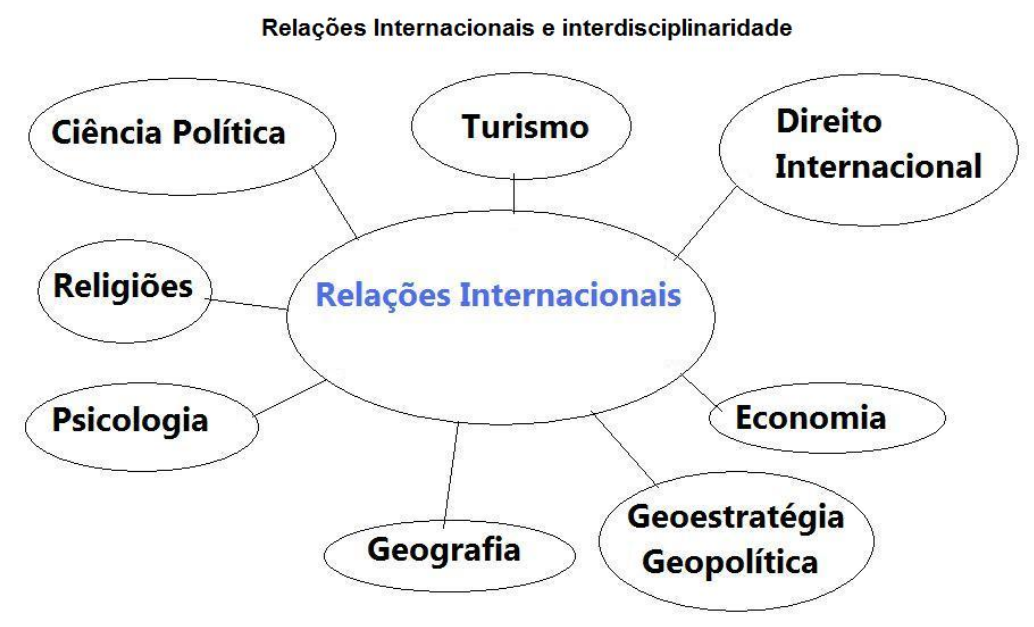

Elab: SANTOS, A.P.

internacionais por ser analisado pelo geógrafo, porém, na perspectiva epistemológica da ciência geográfica, inclusive levando-se em conta ainda as duas grandes áreas "geografia humana" e "geografia física", que produzirão múltiplas explicações sobre o mesmo fenômeno. Entretanto, o espaço geográfico, enquanto objeto central da Geografia é fundamental para a compreensão de todos os fenômenos sentidos, vividos e experimentados pelo ser humano.
Nosso esforço, ao colocar o desafio de desenvolver uma introdução acerca das interfaces teóricas entre geografia, turismo, religião e relações internacionais, de modo sucinto, não poderia ser levado a cabo se não enveredássemos pelo caminho da transdicplinaridade, isto é, ultrapassando fronteiras entre esses campos de estudo, embora tomando como ponto de partida, como guia, a geografia.

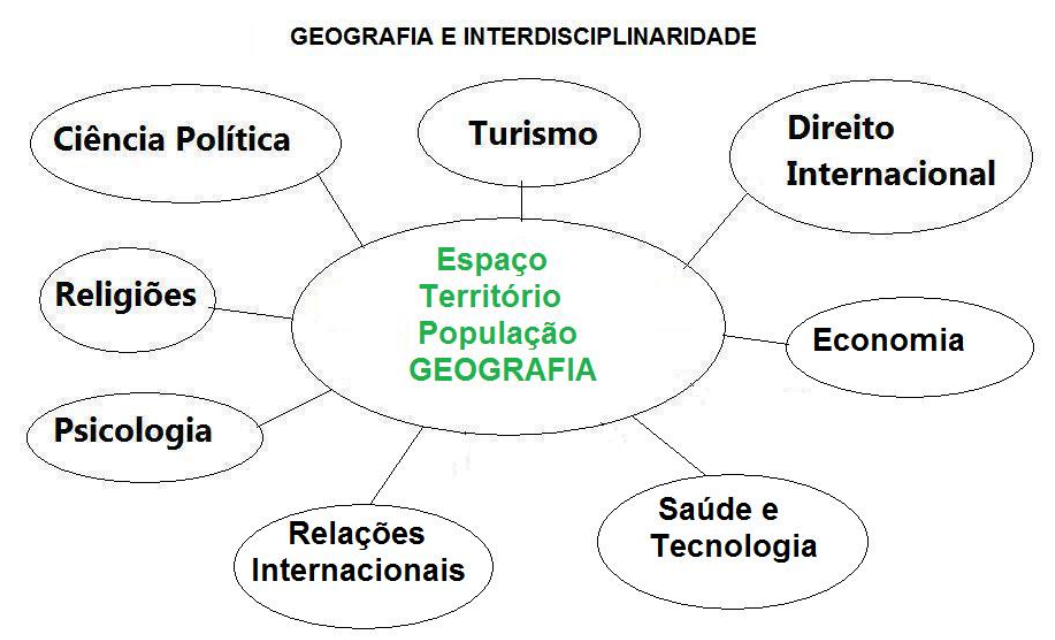

Elab: SANTOS, A.P.

ESPAÇO E CULTURA, UERJ, RJ, N. 35, P.125-151, JAN./JUN. DE 2014

http://www.e-publicacoes.uerj.br/index.php/espacoecultura/ 


\section{A JMJ Rio 2013 - um megaevento religioso turístico internacional}

Antes de adentrarmos à breve exposição sobre o que vem a ser a JMJ, é importante sublinhar que o Vaticano é, de fato, um Estado soberano e, inclusive, com papel de observador na ONU (Organização das Nações Unidas). Ao mesmo tempo, é também a sede da Igreja Católica Apostólica Romana.

A Jornada Mundial da Juventude (JMJ) tem sua origem em 1985, durante o pontificado do Papa João Paulo II (1978 a 2005). Inicialmente realizada em Roma com o objetivo de reunir jovens em torno da fé católica, a JMJ passou a ser realizada a cada dois ou três em outras cidades europeias e de outros continentes, como podemos verificar na tabela a seguir.

Em 2011, após o termino da JMJ na cidade de Madrid, o Papa Bento XVI anunciou que a próxima JMJ seria no Rio de Janeiro, em 2013. Com a inesperada renúncia do cardeal alemão Joseph Ratzinger, em fevereiro de 2013, o Vaticano teve que eleger um novo papa. Pela primeira vez na história da Igreja Católica, o Conclave - reunião dos cardeais mais antigos da cúpula católica -

\begin{tabular}{|l|l|l|}
\hline \multicolumn{3}{|c|}{ JORNADAS MUNDIAIS DA JUVENTUDE -JMJ } \\
\hline ANO & PAÍS & CIDADE \\
\hline 1986 & Itália & Roma \\
\hline 1987 & Argentina & Buenos Aires \\
\hline 1989 & Espanha & Santiago de Compostela \\
\hline 1991 & Polônia & Czestochowa \\
\hline 1993 & Estados Unidos da América & Denver \\
\hline 1995 & Filipinas & Manila \\
\hline 1997 & França & Paris \\
\hline 2000 & Itália & Roma \\
\hline 2002 & Canadá & Toronto \\
\hline 2005 & Alemanha & Colónia \\
\hline 2008 & Austrália & Sydney \\
\hline 2011 & Espanha & Madrid \\
\hline 2013 & Brasil & Rio de Janeiro \\
\hline 2016 & Polônia & Cracóvia \\
\hline Fonte: Elab. SANTOS, A.P. - Rio de Janeiro, UERJ 2014 & \\
\hline
\end{tabular}

ESPAÇO E CULTURA, UERJ, RJ, N. 35, P.125-151, JAN./JUN. DE 2014

http://www.e-publicacoes.uerj.br/index.php/espacoecultura/ 
elegeu um cardeal latino-america para o posto mais alto do catolismo no mundo: o cardeal argentino Jorge Mario Bergoglio foi eleito Papa Francisco, em 13 de março de 2013.

A JMJ Rio 2013 aconteceu entre os dias 23 e 28 de julho, na cidade do Rio de
Janeiro. Além dos cerca de dois milhões de peregrinos populares, participam também 1.500 bispos (50 cardeais) e 1.200 sacerdotes e vários chefes de Estado de países da America do Sul e de outros continentes.

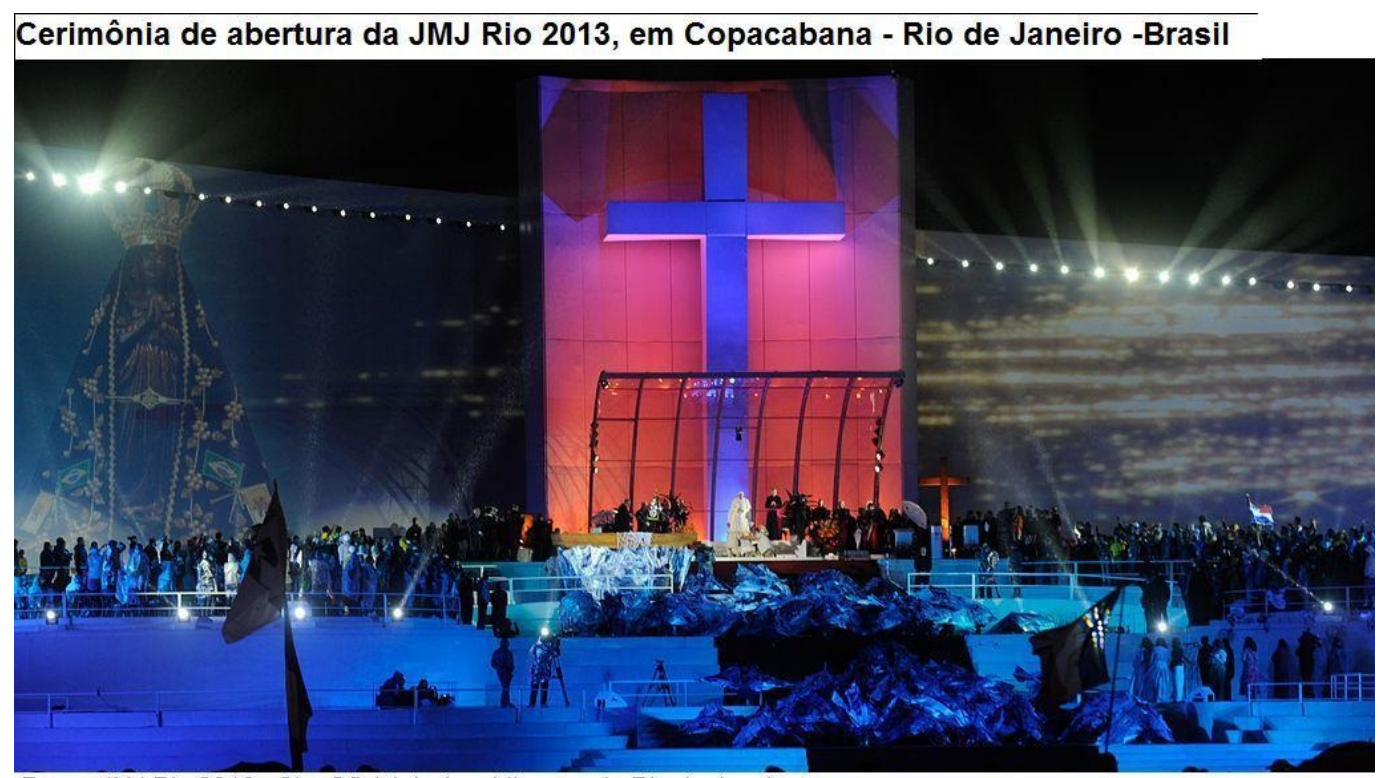

Fonte: JMJ Rio 2013 - Site Oficial da Arquidiocese do Rio de Janeiro.

Missa de Envio ou de Encerramento da JMJ Rio 2013 - Copacabana - Rio de Janeiro

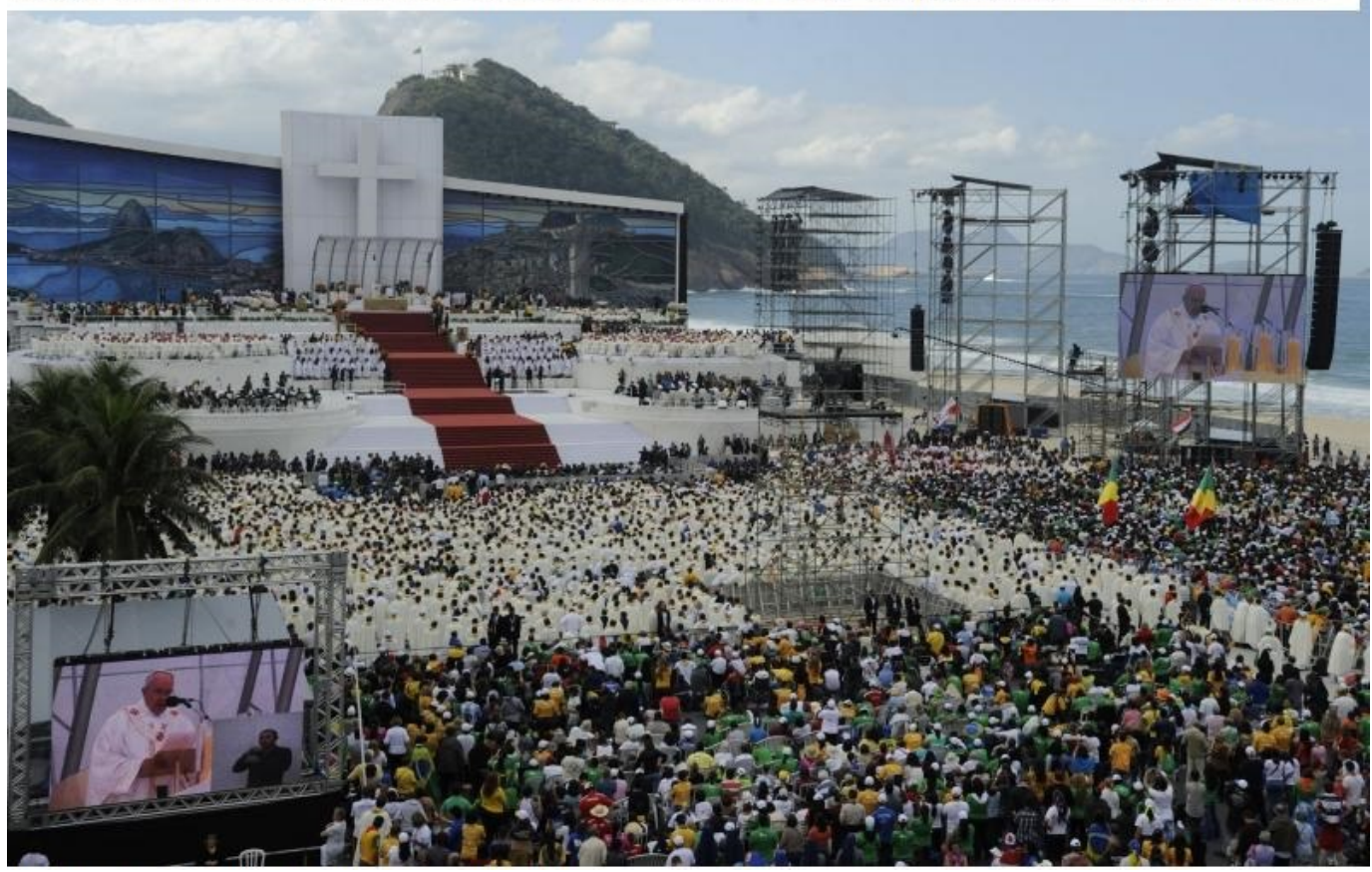

ESPAÇO E CULTURA, UERJ, RJ, N. 35, P.125-151, JAN./JUN. DE 2014

http://www.e-publicacoes.uerj.br/index.php/espacoecultura/ 
Segundo os organizadores e calculos da prefeitura do Rio de Janeiro, na encerramento da JMJ 2013, compareceram cerca de 2,5 milhões de peregrinos católicos. Em meio a essa multidão também compareceram pessoas de outras religiões especialmente motivadas pelo carisma do Papa Francisco.

Mesmo num dia de inverno e nublado, a praia de Copacabana esteve superlotada de pessoas das mais variadas nacionalidades.

A interação de inúmeros turistas peregrinos que ultrapassam suas fronteiras nacionais com destino ao Rio de Janeiro, não se concentrou apenas na capital carioca. Antes da abertura oficial da JMJ Rio 2013, aconteceu a Semana Missionárias em várias cidades da região metropolitana do Rio, a exemplo de Petrópolis e também em cidades da
Região Serrana: Nova Friburgo e Teresópolis.

A cidade de Teresópolis realizou a Semana Missinária com procissão pelas principais ruas e concentração para missa no ginásio de esporte.

Nesta breve exposição acerca da JMJ Rio 2013, um megaevento religioso turístico internacional, pode-se vislumbrar o processo de troca de experiências entre pessoas católicas de inúmeras nacionalidades que se encontraram em território brasileiro, inclusive com a presença de um papa latino-americano. Portanto, denotam-se intrínsecas interfaces entre geografia, turismo, religião e relações internacionais, com a presença do Chefe de Estado do Vaticano, Papa Francisco, bem como também de outros chefes de Estado.

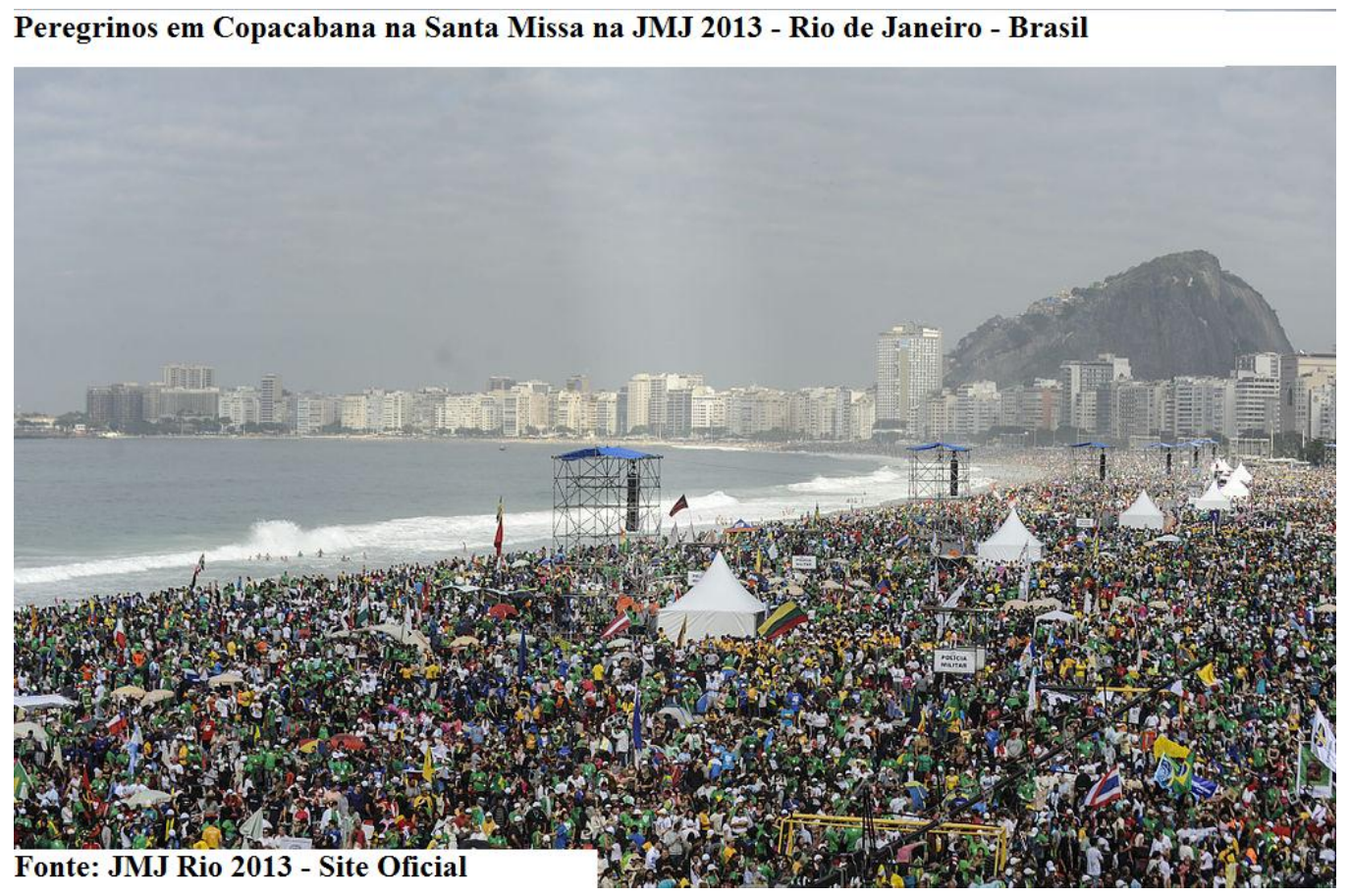

ESPAÇO E CULTURA, UERJ, RJ, N. 35, P.125-151, JAN./JUN. DE 2014

http://www.e-publicacoes.uerj.br/index.php/espacoecultura/ 


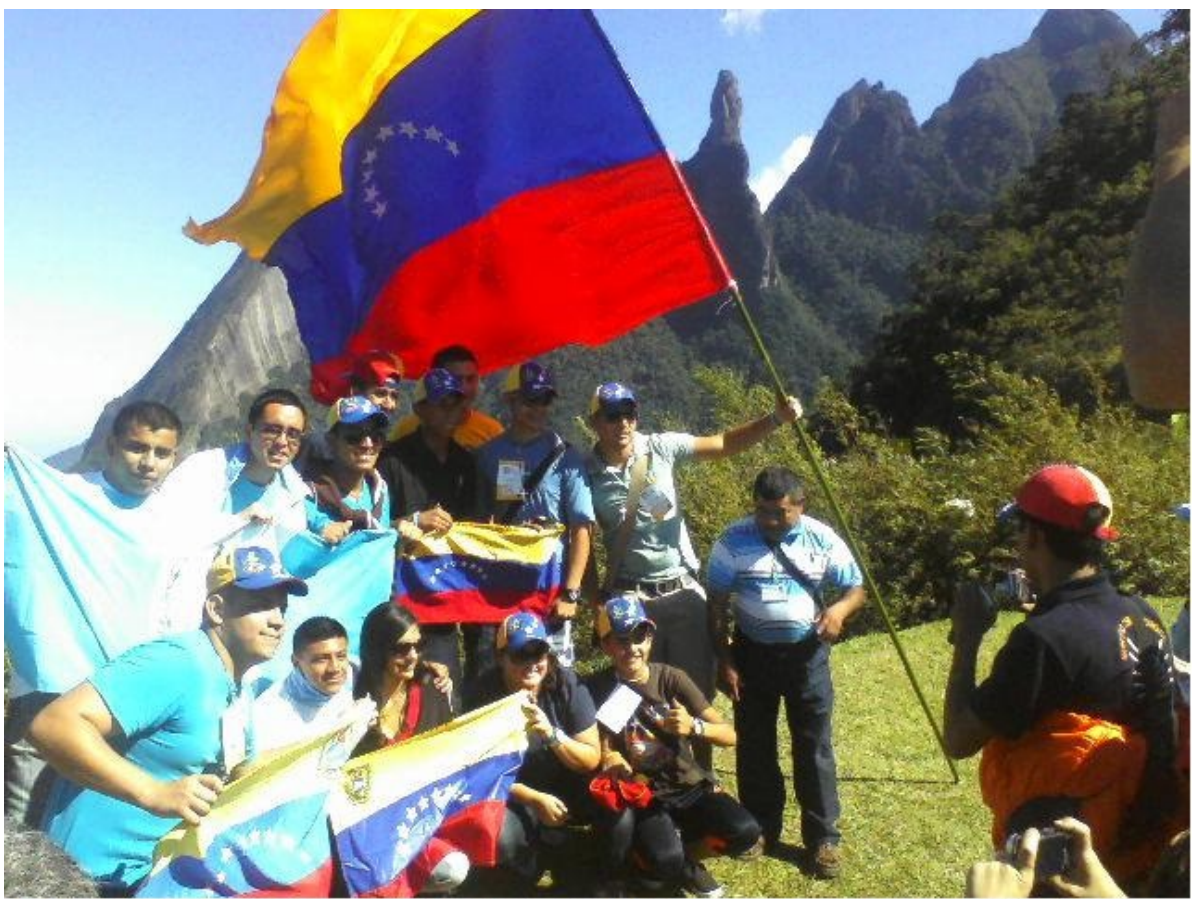

Peregrinos latinos-americanos em Teresópolis-RJ - JMJ Rio 2013 Foto: SANTOS, Alberto P.

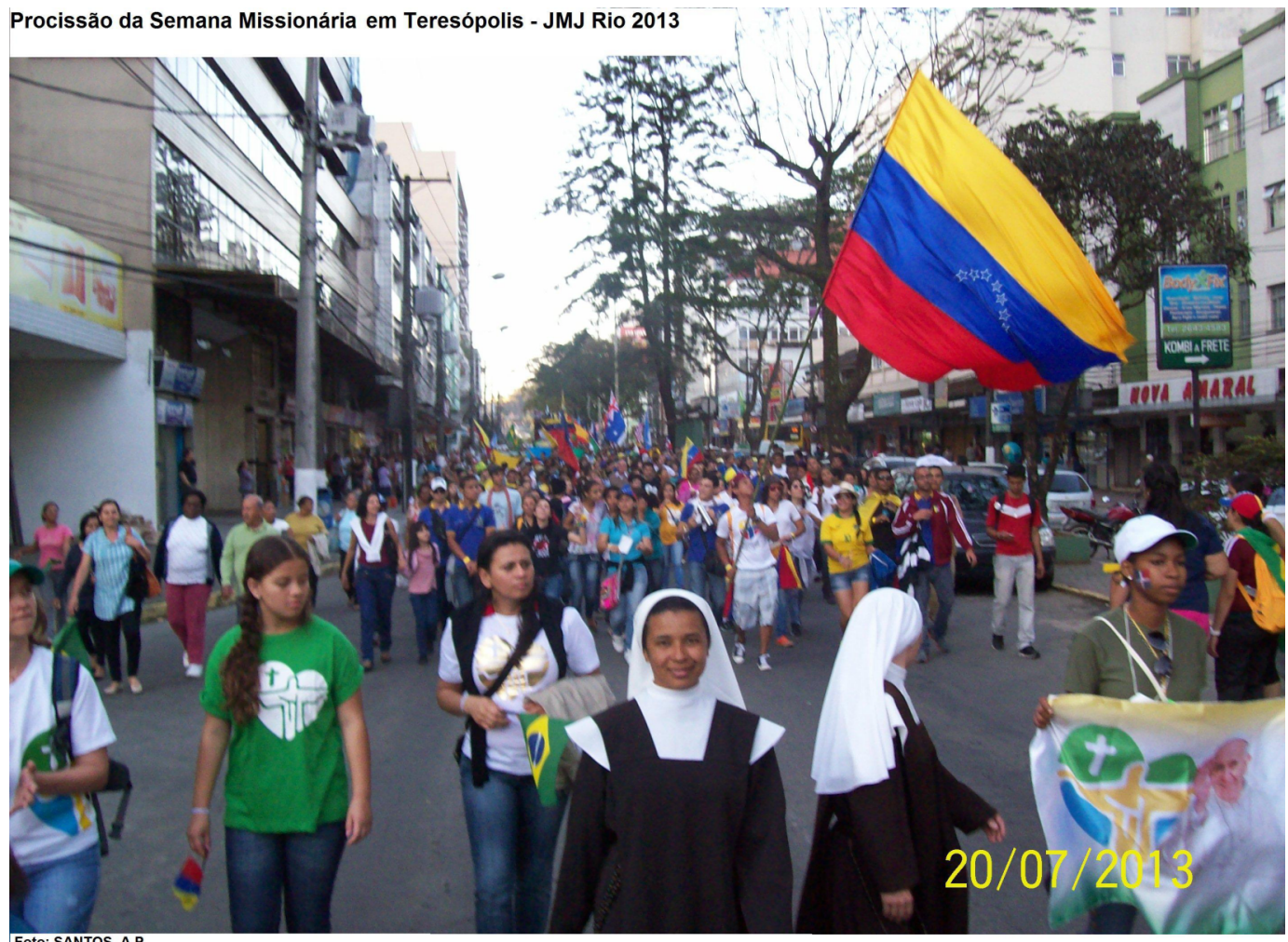

ESPAÇO E CULTURA, UERJ, RJ, N. 35, P.125-151, JAN./JUN. DE 2014

http://www.e-publicacoes.uerj.br/index.php/espacoecultura/ 


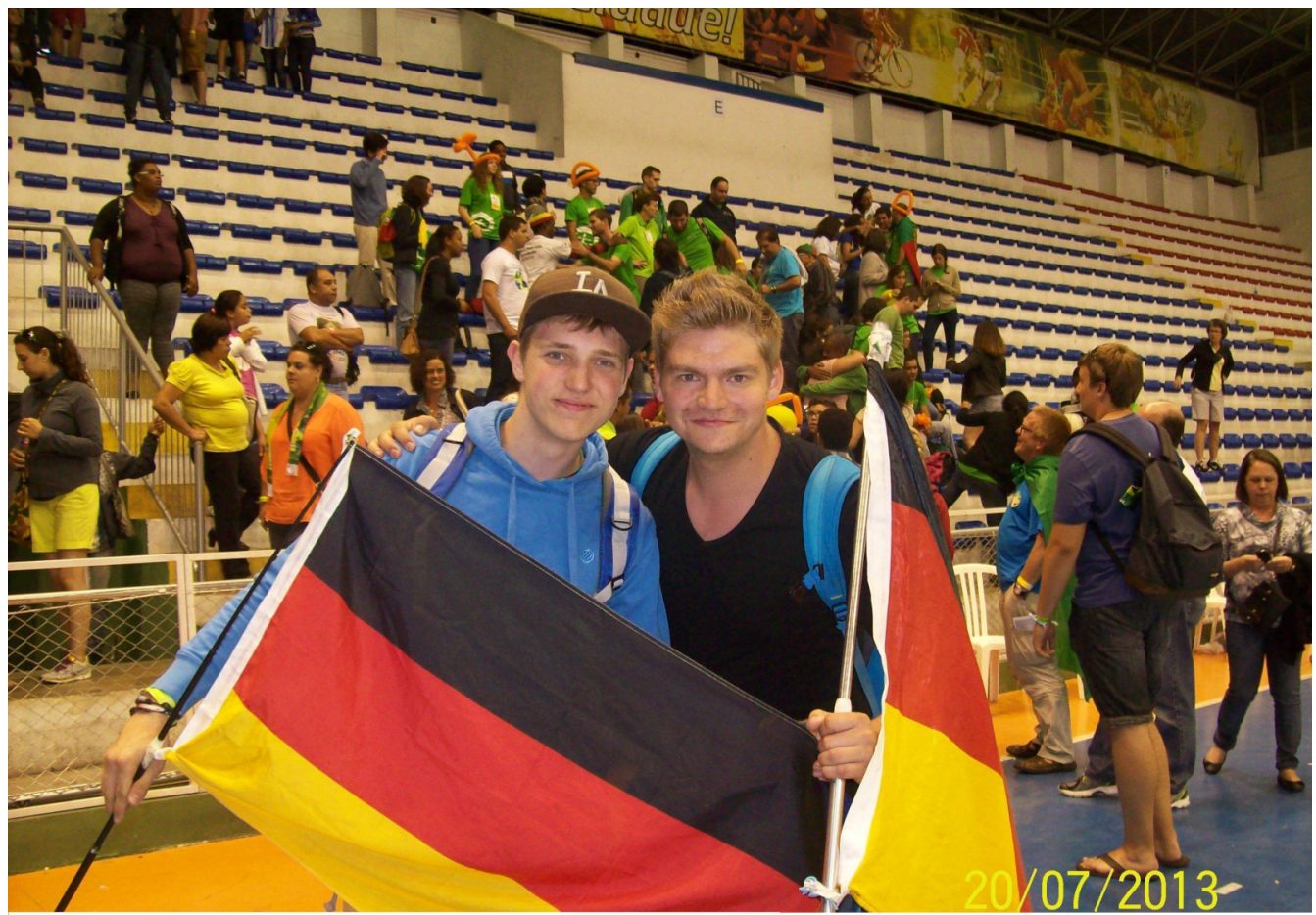

Peregrinos alemães na Semana Missionária em Teresópolis - RJ, JMJ Rio 2013 Foto: SANTOS, Alberto $P$.

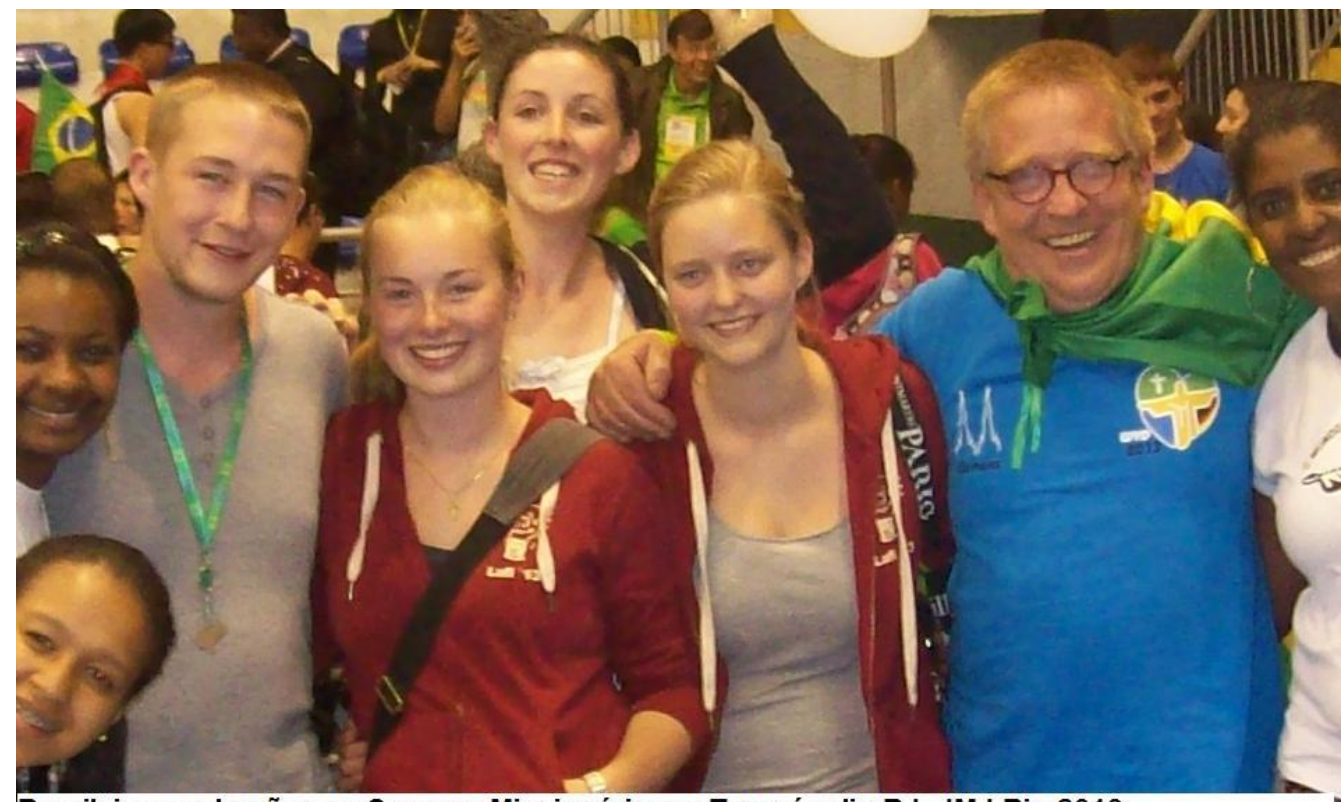

Brasileiras e alemães na Semana Missionária em Teresópolis-RJ, JMJ Rio 2013

Foto: SANTOS. Alberto P.

ESPAÇO E CULTURA, UERJ, RJ, N. 35, P.125-151, JAN./JUN. DE 2014

http://www.e-publicacoes.uerj.br/index.php/espacoecultura/

\section{5}



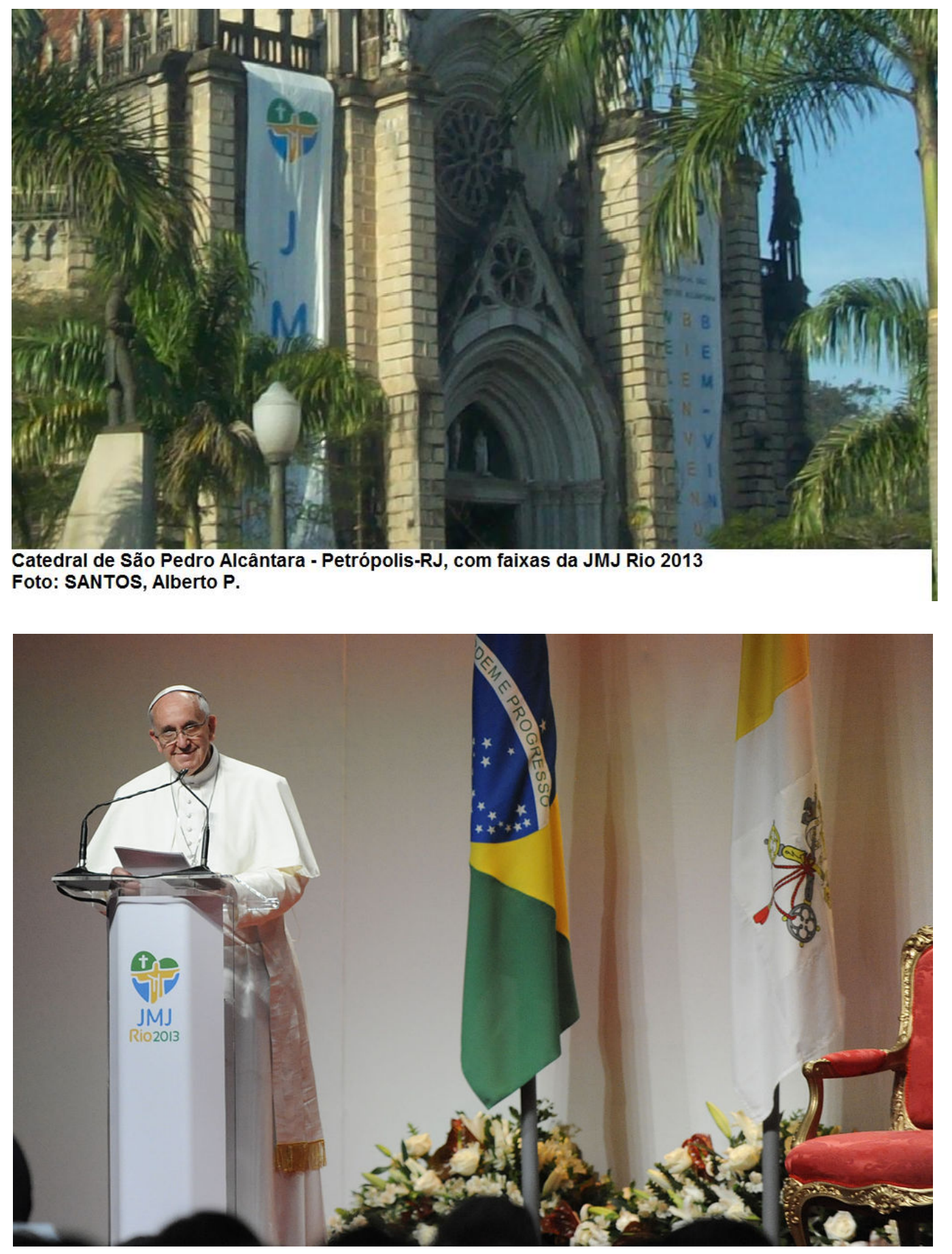

Portanto, entendemos que este Internacionais, embora veremos que essa trabalho sinaliza-se como uma introdução acerca das interfaces teóricas entre Geografia, Turismo, Religião e Relações abordagem é rara e, nesse sentido, aponta para uma linha de pesquisa ainda inexplorada. 


\section{Relações Internacionais, crise de paradigmas e religião}

Vários pesquisadores demonstram com maestria a importância do estudo dos pensadores clássicos das RI para a compreensão do sistema político internacional. Dentre esses pensadores destacam-se os clássicos Maquiavel, Morgenthau e os contemporâneos Raymond Aron, Hedley Bull, James Rosenau, e outros. No entanto, fica claro, segundo os especialistas nesses pensadores, que os paradigmas das RI são heterogêneos, cabendo inclusive visões que, em certa medida, se antagonizam e também visões que se aproximam e/ou se complementam entre os clássicos das RI. (MEDEIROS, et al. 2010).

Além da diversidade dos paradigmas das RI, constata-se também complexidade ao se estudar as RI numa perspectiva histórica - desde as revoluções do século XVIII, (francesa, napoleônica), passando pelas revoluções do século XIX, (industrial, os nacionalismos e o surgimento das ideias comunistas), o curto século XX (as duas grandes guerras 1914-18 e 1939-45, a bipolaridade, o inicio e o fim da Guerra Fria e até a implosão do bloco comunista) - temas esses analisados por vários especialistas em História das RI. (SARAIVA, 2008).

A complexidade das RI, sobretudo após o fim da Guerra Fria que provocou profundas mudanças no sistema político internacional surpreendendo até mesmo internacionalistas, revela também que os paradigmas dominantes nas análises das RI entraram em crise.
No entanto, essa crise de paradigmas nas RI possibilita novas abordagens como, por exemplo, as análises do discurso religioso da "direita cristã" norte-americana com transbordamento para a política externa dos Estados Unidos (MATEO, 2011), bem como outro estudo que analisa a política externa dos Estados Unidos fortalecida pela "(re)produção da ideologia puritana e o discurso de americanidade" em sintonia com a "religião civil como identidade nacional". (RESENDE, 2009).

No contexto de crise dos paradigmas das RI, vários analistas propuseram novas ideias como tentativas de explicar e até mesmo intervir na nova ordem mundial no sistema político internacional em gestação. Nesse sentido, analistas internacionais como Huntington (1997), Fukuyama (1992; 2006), Kennedy (1988), Minc (1994), Ramonet (1998), entre outros, são exemplos de visões que sugerem, ao nosso entendimento, que o estudo das RI na história contemporânea comportam múltiplos olhares.

Essas múltiplas visões ou ideias produzidas por analistas norteamericanos, ingleses e franceses acerca do sistema político internacional, além de explicar o mundo, seriam também ideias que ajudam a redefini-lo. Por exemplo, quando Huntington (1997) propõe a tese de "choque de civilizações" ou quando Fukuyama (1992) defende "o fim da história" com a defesa da democracia liberal, essas ideias seriam também discursos que promovem intervenção no mundo em defesa de seu país, os Estados Unidos (VESENTINI, 2000). 
Esses múltiplos olhares sobre as RI no mundo atual, possibilitam também pensar que o sistema político internacional abriga vários subsistemas como, por exemplo, o subsistema da "Ordem Ambiental Internacional", em construção, segundo a visão do geógrafo Wagner Costa (RIBEIRO, 2001).

Além disso, os múltiplos olhares e estudos de RI permitem entender que as relações no sistema político internacional não estão restritas ao espaço territorial do Estado-Nação, "são relações mais amplas e complexas, não raro envolvendo vasto espectro de atores e, quase sempre, abrangendo diferentes vertentes da sociedade", como sugerem vários cientistas políticos (MEDEIROS et al, 2010, p.17).

Nesse mesmo sentido, referindo-se ao cenário político internacional após a Guerra Fria, o geógrafo J.W.Vesentini (2000) defende que as relações de poder não são apenas exercidas pelos Estados nacionais. Novos atores ou sujeitos participam e interferem nas relações internacionais, desde as civilizações ou grandes culturas até as $\mathrm{ONG}^{\prime} \mathrm{s}$, passando pelas empresas multi ou transnacionais, organizações internacionais (ONU, OMC, FMI, e outras), etc. No cenário das "novas geopolíticas", segundo Vesentini, "novos campos de lutas são agora importantes nas relações de poder no espaço mundial, como a questão ambiental, as lutas pelos direitos das mulheres, das minorias étniconacionais, de grupos com diferentes orientações sexuais, etc". (VESENTINI, 2000, p.11)

Entre vários estudiosos da história das relações internacionais contemporâneas, o cenário mundial neste século XXI sugere diferentes paradigmas de conformação dos poderes no sistema político internacional. Dentre esses estudiosos, a visão de José Flávio S. Saraiva sugere que "o sistema político internacional apresenta alto grau de anarquia transicional" (SARAIVA, 2008, p. 346).

Analisando a história das relações internacionais contemporâneas, um historiador internacionalista sugere novos temas de pesquisa para o século XXI, como a diversidade cultural, os processos sociais de identidade e a "hipoteca das religiões sobre as mentalidades" (MARTINS, 2008, p.IX).

\section{Transcendência e Religião nas Relações Internacionais}

Ao olhar para o passado da história das relações internacionais no Ocidente, constata-se que a regulação dos conflitos políticos, econômicos e religiosos nos territórios era exercida internacionalmente pelo poder papal. Esse sistema político-religioso foi radicalmente abalado com a Reforma Protestante (1517), seguido por inúmeras guerras religiosas, entre católicos e protestantes como, por exemplo, a Guerra dos Trinta Anos (1618-1648). Fora do controle do poder papal, esse cenário de guerras religiosas teve um fim somente com o Tratado de Paz de Westfália (1648), no qual se estabeleceu o reconhecimento da soberania dos Estados em processo de formação (ROMANO, 2008). 
Pode-se considerar que desde o Tratado de Paz de Westfália as RI se pautaram, em certa medida, na visão de racionalidade que fundamenta o Estado moderno, colocando a religião cada vez mais num plano secundário no sistema político internacional.

Contudo, segundo Huntington, "a separação westfaliana da religião e da política internacional, produto idiossincrático da civilização ocidental, está chegando ao fim, e a religião tem probabilidade cada vez maior de se imiscuir nos assuntos internacionais". (HUNTINGTON, 1997, p.62)

No entanto, em que medida e como atores internacionais poderiam imiscuirse, por exemplo, na política nacional brasileira através da religião?

Essa é uma questão que merece ser investigada. Ressalta-se, porém, um fato recente como evidência: nas eleições democráticas de 2010 para presidente da República Federativa do Brasil, o segundo turno das eleições foi invadido pela religião, tanto a Igreja Católica como algumas Igrejas Evangélicas. Por exemplo, até mesmo o Papa Bento XVI recomendou aos Bispos brasileiros que orientassem aos fiéis politicamente para não votarem em candidato que entende o aborto como problema de saúde pública e não como assunto religioso. ${ }^{2}$

Afinal, após longo processo de secularização, estaríamos como sugeriu Alain Minc (1994), voltando à nova Idade Média? A história seria cíclica?

Dentre as profundas transformações sociais e políticas entre os séculos XVIII e XIX que marcaram a Era das Revoluções (1789-1848), o historiador Eric Hobsbawm (1977) destaca, de um lado, a revolução da ideologia religiosa e, de outro, a revolução da ideologia secular.

Hobsbawm (1977) demonstra que até antes de 1848, os termos em que todos os homens - com raras exceções pensavam o mundo eram segundo a visão da religião tradicional. Contudo, a ideologia secular transformou radicalmente a vida social naquele contexto.

Ao passo dos avanços do secularismo no processo revolucionário do século XIX, as "seitas protestantes" também cresceram significativamente, uma vez que para a massa da população, o retorno à religião era um método de luta contra a sociedade cada vez mais fria, desumana e tirânica do liberalismo da classe média (HOBSBAWM, 1977).

Contudo, o secularismo avançou em toda a sociedade, tendo sido aprofundado no século XX. Haveria, porém, lugar para as religiões na História das Relações Internacionais no século $\mathrm{XXI}$ ?

Segundo Hobsbwam, as forças históricas que moldaram o século XX continuam a operar neste século XXI. E dentre essas forças históricas destaca-se a Revolução Islâmica no Irã em 1979, cujo fato histórico surpreendeu até mesmo o serviço secreto (CIA) do governo norteamericano (MATEO, 2011).

Nos estudos das RI o tema da religião não foi devidamente analisado. Afinal, desde a Paz de Westfália, com a distinção dos poderes espirituais e temporais, em tese, a religião não deveria se envolver nas coisas da vida pública. 
No entanto, há que se considerar o papel desempenhado pelo Vaticano no decorrer da Guerra Fria, especialmente sua influência política para a derrocada do regime soviético no Leste Europeu e também no combate à expansão das ideias marxista nas Comunidades Eclesiais de Base (CEB's), inspiradas pela Teologia da Libertação na América Latina. Nesse contexto, a geopolítica do Vaticano esteve em aliança com a "direita cristã" norteamericana, especialmente a partir do governo do presidente Ronald Reagan na década de 1980 (COLONNA-CESARI, 1993).

Além desse papel de destaque do Vaticano no processo de derrocada do "socialismo real", há que se considerar na história das RI os encontros e desencontros entre a Santa Sé e a República Popular da China, de 1949 a 2005, analisado com lucidez pela historiadora Anna Carletti na obra “Diplomacia e Religião” (CARLETTI, 2008).

Com o fim do período histórico da Guerra Fria, porém, um analista norteamericano das relações internacionais considerou que a nova ordem mundial que se desenhava a partir do inicio da década de 1990, teria forte influência cultural e religiosa, levando-o até mesmo a afirmar que "ao lidar com uma crise de identidade, o que conta para as pessoas é sangue e crença, fé e família." (HUNTINGTON, 1997. p.154).

Temos a considerar que o cenário religioso no Brasil tem relação com o sistema político internacional, de um lado, a influência da geopolítica do Vaticano (COLONNA-CESARI, 1993) e, de outro lado, o pensamento político norte-americano que defende a expansão do protestantismo - especialmente o pentecostalismo - no território brasileiro e no mundo atual. (BERGER \& HUNTINGTON, 2004; BERGER, 2001).

Contudo, poder-se-ia objetar: na sociedade técnico-científica atual, cujo avanço da ciência se expande e o acesso ao conhecimento se democratiza não estaríamos chegando à morte, ao fim, à extinção da religião?

$\mathrm{Na}$ visão de Sigmund Freud (1856-1939), considerado como o pai da psicanálise, a religião nada mais seria que uma "ilusão necessária", uma manifestação da frustração da infância em relação à ausência paterna, que na vida adulta o homem expressaria através do apego à religião, ao mito de um "pai mais poderoso" para amenizar ou escamotear o sentimento de desamparo frente às vicissitudes da vida. Na medida em o homem adquirisse conhecimento científico se afastaria da religião. Nesse sentido, segundo o pensamento freudiano na obra "O Futuro de uma Ilusão", a religião estaria destinada ao fim com a crescente autonomia do ser humano. (FREUD, 1997)

Entretanto, mesmo com o avanço da ciência e a democratização do acesso ao conhecimento, bem como o forte impacto da globalização, a religião continua influenciando a vida das pessoas no cotidiano e até mesmo influenciando na vida pública nos Estados nacionais e nas relações internacionais. Como defende Peter Byer, "a resistência a, ou, talvez, melhor, a digestão da globalização em diversas partes de mundo contemporâneo deu 
origem a movimentos informados pela opção religiosa conservadora." (BYER, 1994).

Nesse sentido, destaca-se que para o sociólogo francês Émile Durkheim (1858-1917), a origem da religião é essencialmente humana, social; por esta razão ela não estaria destinada a desaparecer da sociedade, ao contrário, a religião permaneceria no mundo, porém, seria chamada a se transformar, a se adaptar à realidade. Além disso, segundo Durkheim, não existe religião falsa, todas as religiões são verdadeira à sua maneira (DURKHEIM, 2004).

Além da concepção durkheimiana, merece ser destacada a visão de um historiador das religiões. Mircea Eliade defende que mesmo o homem moderno a-religioso, traz a herança do homo religiosus nas profundezas de seu inconsciente. Nesse sentido, a estrutura mitológica estaria presente até mesmo no comunismo e em seu sentido escatológico proposto por Karl Marx. (ELIADE, 2001)

Segundo Eliade (2001), ao propor o comunismo e o papel do proletariado como redentor dos sofrimentos do mundo, Marx retoma e prolonga um dos grandes mitos escatológicos do mundo asiático mediterrâneo: o justo, o eleito, o ungido, o mensageiro, nos dias atuais na figura do proletariado. Seria ainda o enriquecimento do mito da luta final entre o Bem e o Mal, ou entre o Cristo e o Anticristo, sendo a vitória do primeiro simbolizado pela vitória do proletariado com o fim das classes sociais, idealizado por Marx.

Nesse sentido, entendendo que a transcendência, o mito, a religiosidade está presente no inconsciente humano, temos ainda a visão de Edgar Morin que propõe a teoria da complexidade e defende que a noosfera - esfera das coisas do espírito - é intrínseca à estrutura biofísico-psíquica do Homo Complexus (MORIN, 2005).

Nas palavras de Morin:

"Devemos estar bem conscientes de que, desde o alvorecer da humanidade, encontra-se a noção de noosfera - a esfera das coisas do espírito -, com o surgimento dos mitos, dos deuses, e o extraordinário levante dos seres espirituais impulsionou e arrastou o Homo sapiens a delírios, massacres, crueldades, adorações, êxtases e sublimidades desconhecidas no mundo animal. (...) Os humanos possuídos são capazes de morrer ou matar por um deus, por uma ideia. (MORIN, 2005, p.28-29).

Assim sendo, se a noosfera, isto é, a "esfera das coisas do espírito" (MORIN, 2005), é parte da complexidade humana, como relacioná-la à esfera política do Estado e às relações internacionais?

Nos estudos das Relações Internacionais durante décadas a religião foi marginalizada. Somente a partir da década de 1980 e 1990, a religião começou a surgir nos estudos de Relações Internacionais. (MATEO, 2011; RESENDE, 2009)

Contudo, pelo menos desde o inicio do século XX o sociólogo alemão Max Weber (1864-1920) havia 
enfatizado a importância do estudo da religião para a formação da cultura e para a constituição da política no Estado nacional. No entanto, segundo Weber "o homem moderno, mesmo com a melhor das vontades, costuma ser incapaz de atribuir às ideias religiosas a importância que merecem em relação à cultura e ao caráter nacional." (WEBER, 2004, p.136)

Ressalta-se que, segundo Weber, a ação religiosa é uma ação racional, ou pelo menos se orienta pelas regras da experiência, e está voltada para este mundo (não para o além), sendo que seus fins são de natureza econômica. (WEBER, 1984). Na obra "A Ética Protestante e o Espírito do Capitalismo", Weber demonstra a importância fundamental de certo protestantismo - o calvinismo - na formação do capitalismo, uma vez que a doutrina calvinista da predestinação interpreta o êxito material como garantia da graça divina. (WEBER, 2004)

Vale ressaltar que, nas décadas de 1950/60 sociólogos da religião elaboraram a teoria da secularização, cuja ideia central era que a modernidade (progresso da ciência e da tecnologia) eliminaria a religião da sociedade, uma vez que a separação entre Estado e Igreja reduziu drasticamente a influência da religião na vida pública. Nesse sentido, a civilização ocidental que já estava diante do desencantamento do mundo passou a ser cada vez mais secularizada, laica, profana, não-religiosa (PIERUCCI, 2003).

Entretanto, passadas algumas décadas, Peter Berger, sociólogo norteamericano da Universidade de Boston, um dos idealizadores da teoria da secularização, publicou, em 1999, a obra
"A Dessecularização do Mundo" cuja ideia central é que a teoria da secularização era essencialmente falsa ou equivocada. Ou seja, Berger refuta a teoria da secularização com uma nova ideia, a teoria da dessecularização. Agora, segundo ele, o mundo é essencialmente religioso, "e tão ferozmente religioso quanto antes, e até mais em certos lugares". (BERGER, 2001, p.10).

No contexto do pós-Guerra Fria a revalorização das tradições culturais e religiosas, bem como os conflitos étnicoreligiosos ganhou destaque na geografia política mundial. Por exemplo, o atentado terrorista às torres do World Trade Center, nos Estados Unidos, no 11 de setembro de 2011, cuja autoria foi assumida pela Al Qaeda, organização fundamentalista islâmica liderada pelo saudita Osama Bin Laden -, revela a importância política das religiões no cenário mundial e impulsiona a necessidade de leitura e estudo das religiões neste século XXI.

Sob o comando do presidente George Walker Bush (do partido republicano e evangélico da Igreja Metodista Nova), as forças armadas norte-americanas bombardearam o Afeganistão e invadiram o Iraque, ambos os países islâmicos, como pretensa resposta ao terrorismo fundamentalista. $\mathrm{Na}$ eleição presidencial dos Estados Unidos, em novembro de 2004, a sociedade norte-americana viveu uma forte onda de conservadorismo religioso que favoreceu decisivamente a reeleição do presidente Bush (FUKUYAMA, 2006). É curioso observar que desde 
1989 surgiu nos Estados Unidos, entre os evangélicos, a ideia da chamada "Janela 10-40", isto é, espaço geográfico localizado entre os paralelos $10^{\circ}$ e $40^{\circ}$ ao norte da linha do Equador, abrangendo todo o norte do continente africano (África Islâmica ou Branca), o Oriente Médio, a India, até o extremo leste da Ásia (veja cartograma a seguir):

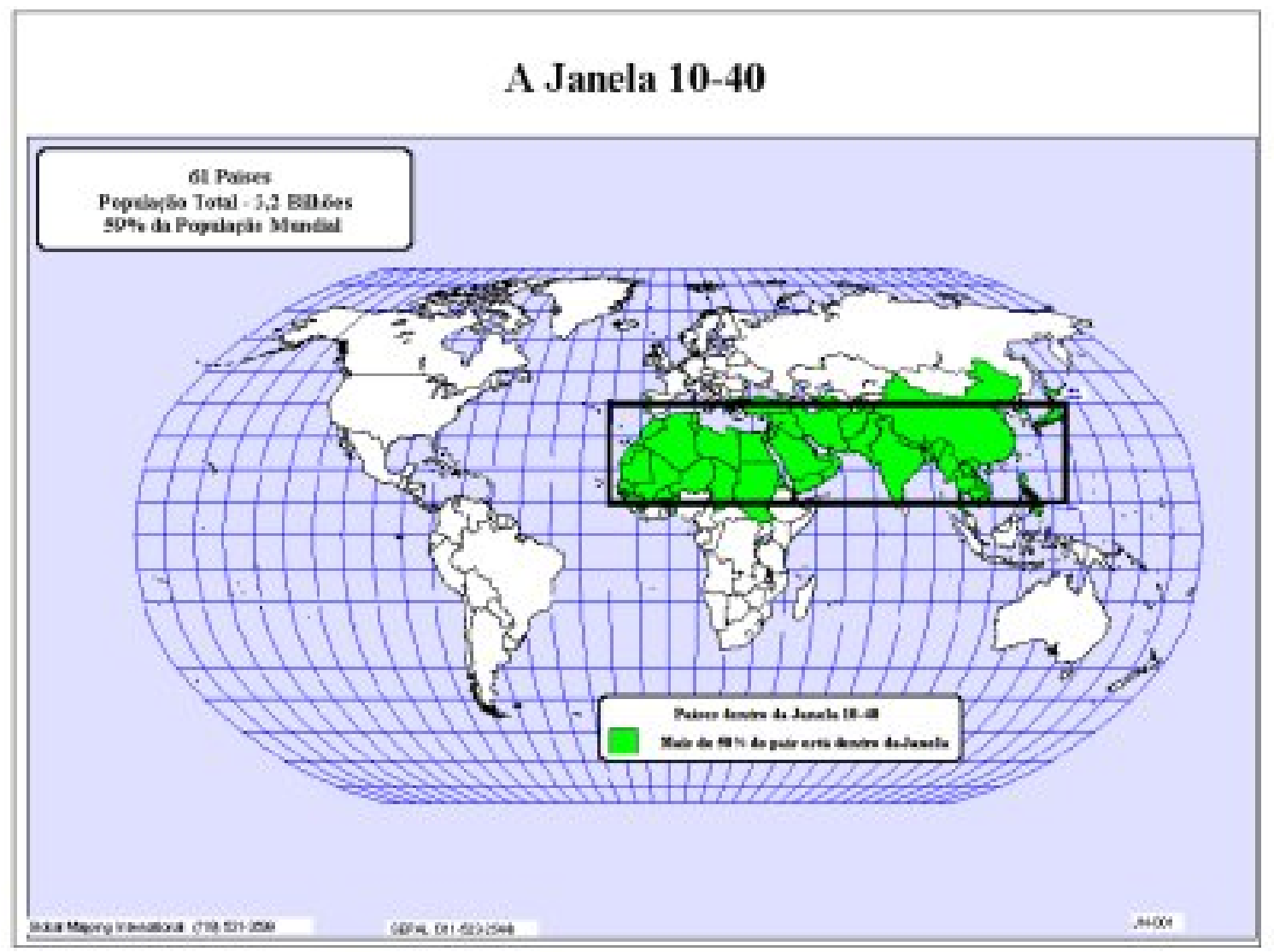

$\mathrm{Na}$ região da "Janela $10-40$ " as religiões predominantes são o islamismo, o hinduísmo e o budismo. Segundo as igrejas evangélicas de missões, essa região é pobre e vive em conflitos porque ainda não é uma região cristã, por isso deve ser conquistada e cristianizada para que se torne uma região rica e abençoada.

Nesse sentido, nota-se que no século XXI a religião começa a atrair o interesse de estudiosos das Relações Internacionais, uma vez que a religião influencia a política externa de uma das maiores potência mundial da atualidade, a saber, os Estados Unidos da América.

Estudos recentes na área de RI estão apontando a importância da religião na política externa dos EUA como, por exemplo, a tese de doutorado da cientista política Érica Simone Resende que analisa a (re)produção da ideologia puritana e o discurso de americanidade da religião civil nos Estados Unidos, após o episódio do 11 de setembro (RESENDE, 2009). 
Outro estudo acadêmico recente "Deus abençoe a América: religião, política e Relações Internacionais dos Estados Unidos", de Luiza Rodrigues Mateo, analisa a influência da religião desde a fundação dos Estados Unidos até o final do século $\mathrm{XX}$, com o recente movimento civil organizado pela "direita religiosa" influenciando o Congresso Nacional e a política externa dos Estados Unidos. (MATEO, 2011).

Por fim, vale ressaltar que se, de um lado, a globalização desagrega e provoca crise de identidade nas pessoas, por outro lado, o turismo internacional no contexto da condição pós-moderna neste século XXI, especialmente com a velocidade da comunicação e dos meios de transportes provoca a sensação da redução das distâncias no espaço facilitando o contato com povos de outros continentes, portanto, colocandonos mais próximo ao outro, ao estranho, ao diferente. A esse fenômeno o geógrafo David Harvey (1994) sintetizou com a expressão "compressão do espaço-tempo", como simbolizamos com a figura a seguir:

\section{Globalização - "COMPRESSÃO DO ESPAÇO-TEMPO"}

Condição Pós-moderna - HARVEY, David. 1994

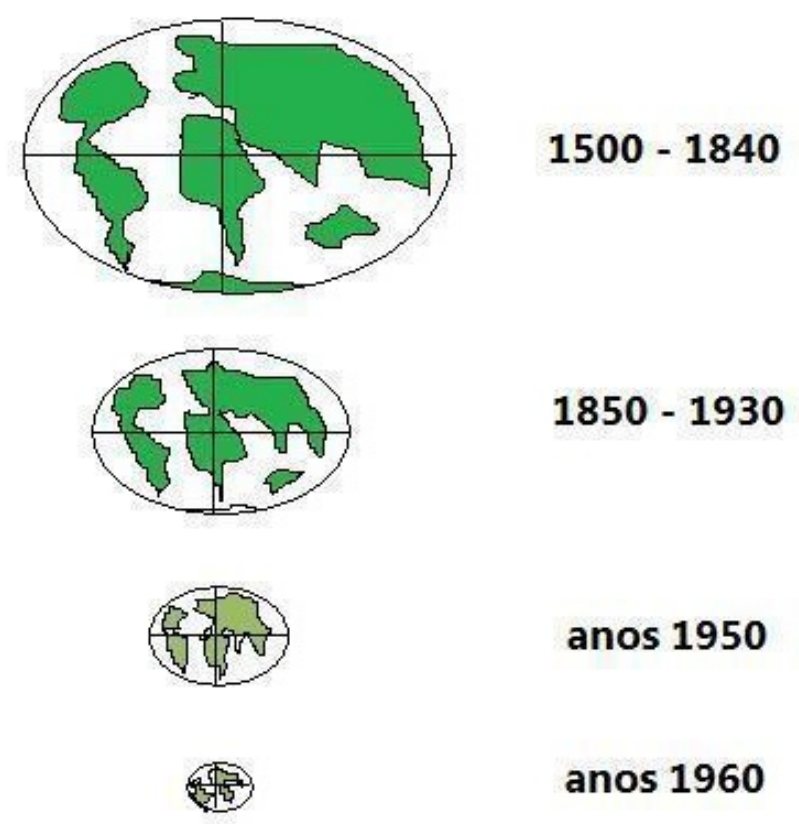

Fonte: Elaborado pelo Autor. 2012 
A globalização não só trouxe impactos na economia internacional, como também no campo religioso mundial produziu efeitos inesperados, desafiando especialistas em congressos internacionais a repensar seus paradigmas e conceitos na área de antropologia e de sociologia da religião. (ORO, 1999).

Contudo, a nosso ver, o turismo internacional e a globalização, de modo geral, possibilita aos turistas, e ao ser humano em particular, pensar e repensar seus valores, buscando novos caminhos da religiosidade que leva em conta, também, o desenvolvimento da autonomia da fé com diálogo transreligioso e tolerância aberta para a construção de uma nova ordem espiritual planetária.

Refletindo sobre a "grande mutação contemporânea” e a globalização atual, o geógrafo Milton Santos finalizou sua obra com esperança: Agora que estamos descobrindo o sentido de nossa presença no planeta, pode-se dizer que uma história universal verdadeiramente humana está, finalmente, começando. (...) Muito falamos hoje nos progressos e nas promessas da engenharia genética, que conduziriam a uma mutação do homem biológico, algo que ainda é do domínio da história da ciência e da técnica. Pouco, no entanto, se fala das condições, também hoje presentes, que podem assegurar uma mutação filosófica do homem, capaz de atribuir um novo sentido à existência de cada pessoa e, também, do planeta. (SANTOS, 2000, p. 174):
Por sua vez, valorizando o estudo da geografia das civilizações para o século XXI, inspirado nas ideias do historiador Arnold Toynbee, bem como na experiência cultural dos anos de 1968, Roland Breton conclui:

A dialética entre imanência e transcendência está na base da gênese das civilizações. Isto é o que deveriam ter em mente todos aqueles que sonham ou atuam em prol de uma nova ordem mundial, do futuro de nossas civilizações, particulares... ou planetárias, e deverão encontrar, mesmo para o século XXI, mitos fundadores e perspectivas escatológicas." (BRETON, 1990, p.124)

É nessa perspectiva que se insere esta reflexão, cuja questão central motivadora merece ser colocada novamente: numa nova visão, diferente da tese do "choque de civilizações" (HUNTINGTON, 1997), qual seria o papel ou a contribuição das religiosidades no Brasil para a paz mundial e para a construção de uma nova ordem espiritual na história das relações Internacionais?

Mais que tolerância religiosa, acredita-se hoje que é urgente pensar na construção do diálogo transreligioso. Esse diálogo transreligioso, a nosso ver, está na esfera da autonomia da fé, porém, com apoio mútuo entre as pessoas; acontece de baixo para cima e em todas as direções com respeito ao outro, ao diferente, entre pessoas religiosas das diversas crenças e também diálogo com aqueles que se declaram sem religião, porém, possuem espiritualidade. Afinal, as religiosidades dos brasileiros estão em mutação, talvez, sinalizando para a invenção brasileira de outra ordem 
espiritual.

Ao contrário da tese de choque de civilizações, caberia pensarmos a respeito do papel do Brasil e das religiosidades dos brasileiros no cenário das relações internacionais neste século XXI. Pensarmos na construção do diálogo entre as religiosidades sobre novas epistemologias e ontologias que possibilitem, por exemplo, olhar para o mundo islâmico, como sugere o historiador Peter Demant, não a partir da visão etnocêntrica do Ocidente, mas olhar o islamismo em sua riqueza que carece e permite também o diálogo com o outro, diálogo entre as fés e civilizações (DEMANT, 2008).

\section{Considerações finais}

O objetivo central deste trabalho foi demonstrar, sucintamente, que existem interfaces teóricas entre Geografia, Turismo, Religião e Relações Internacionais. Embora este trabalho seja apenas uma introdução teórica, entendemos que sua contribuição sinaliza para uma linha de pesquisa em Geografia, especialmente numa abordagem que privilegia as relações entre espaço e cultura.

Entretanto, optamos por tentar enveredar pelos caminhos da transdisciplinaridade, isto é, ultrapassando as fronteiras do conhecimento dos respectivos áreas ou campos disciplinares indicados no título deste trabalho.

Reconhecemos que existe enorme escassez de estudos focados em reflexões que priorizem as interfaces dos conhecimentos e saberes disciplinares aqui sinalizados, seja no campo da Geografia, no Turismo e menos ainda especificamente no campo das Relações Internacionais.

Portanto, com este trabalho introdutório, esperamos contribuir para a sensibilização de outros geógrafos humanistas, bem como turismólogos e outros especialistas no sentido dos estudos teóricos e empíricos acerca das interfaces dos conhecimentos e saberes disciplinares da geografia, do turismo, da religião e das relações internacionais.

\section{Notas}

${ }^{1} \mathrm{O}$ autor é geógrafo. Doutor e mestre em geografia humana pela USP, Universidade de São Paulo. Atualmente é professor adjunto da UERJ, Universidade do Estado do Rio de Janeiro, atuando no Departamento de Turismo e no Programa de Pós-graduação em Geografia do IGEOG, Instituto de Geografia. Tem artigos publicados pelas revistas GEOUSP e GeoUERJ, versando sobre os seguintes temas: geografia, turismo religioso, tolerância religiosa, geopolítica das igrejas, geoética e relações internacionais.

2 FOLHA DE SÃO PAULO, 28/10/2010. Vale lembrar que o segundo turno das eleições aconteceu no dia seguinte ao pronunciamento do papa. 0 assunto foi amplamente divulgado na mídia durante todo o segundo turno das eleições. Por exemplo, de um lado, a revista VEJA publicou matéria de capa com a foto da candidata Dilma Rousseff (PT), 
destacando o assunto aborto (edição 2187 - 13/10/2010) e, de outro lado, a revista ISTOÉ publicou reportagem com a foto do candidato a presidente José Serra ( PSDB) beijando um crucifixo, na capa da revista, com o título "Santos e Santinhos de uma guerra suja". (ISTOÉ 2137 $22 / 10 / 2012$ ).

\section{Referências Bibliográficas}

BEYER, Peter F. "A privatização e a influência pública da religião na sociedade global". IN: FEATHERSTONE, Mike (Org.). Cultural Global nacionalismo, globalização e modernidade. Petrópolis: Vozes, 1994.

BERGER, Peter. Dessecularização do mundo: uma visão global. Rio de Janeiro: Religião e Sociedade, vol.21, no1, 2001.

BERGER, Peter \& HUNTINGTON, Samuel P. (Org.). Muitas Globalizações Diversidade Cultural no mundo contemporâneo. Rio de Janeiro, 2004.

BULL, Hedley. A sociedade anárquica: um estudo da ordem na política mundial. Brasília: Ed. UnB, 2002.

CAPRA, Fritjof. O Tao da Física. São Paulo: Cultrix, 1984.

CARLETTI, Anna. Diplomacia e Religião: encontros e desencontros nas relações entre a Santa Sé e República Popular da China de 1949 a 2005. Brasília: FUNAG, 2008.

COLONNA-CESARI, C. Urbi Et Orbi - A
Geopolítica do Vaticano. Lisboa-Portugal: Caminho, 1993.

DEMANT, Peter. 0 Mundo Muçulmano. $2^{\text {a }}$ ed. São Paulo: Contexto, 2008.

DURKHEIM, Émile. As Formas Elementares de vida Religiosa. São Paulo: Martins Fontes, 2004.

ELIADE, Mircea. O Sagrado e o Profano. São Paulo: Martin Fontes, 2001.

FONSECA, Alexandre B. Nova Era Evangélica, Confissão Positiva e o crescimento dos sem-religião. Numen: revista de estudos e pesquisa da religião. v.3, n.2, 2000, pp. 63-90.

FUKUYAMA, Francis. 0 dilema americano. Rio de Janeiro: Rocco, 2006. O fim da História e o último Homem. Rio de Janeiro: Rocco, 1992. HARVEY, David. Espaços de Esperança. São Paulo: Loyola, 2004.

Paulo: $\quad$ Loyola, 1994.

HOBSBAWM, Eric. Era dos Extremos - o breve século XX 1914-1991. São Paulo: Cia. das Letras, 1995.

A Era das Revoluções (17891848). São Paulo: Paz e Terra, 1977.

HUNTINGTON, Samuel. O Choque de Civilizações e a recomposição da Ordem Mundial.Rio de Janeiro: Objetiva, 1997. 
KENNEDY, Paul. Ascensão e queda das grandes potências. Rio de Janeiro: Campus, 1988.

LACOSTE, Yves. A Geografia, isso serve, em primeiro lugar, para fazer a guerra. Campinas-SP: $\quad$ Papirus, 1989.

LAQUEUR, Walter. Os últimos dias da Europa - Epitáfio para um velho continente. Rio de Janeiro: Odisséia, 2007.

MAQUIAVEL, N. O Principe. Porto Alegre: LP\&M, 1998.

MARTINS, Estevão C. R. Prefácio - História das Relações Internacionais contemporâneas. São Paulo: Saraiva; Brasília: $\quad$ IBRI, 2008.

MATE0, Luiza R. Deus abençoe a América: religião, política e relações internacionais dos Estados Unidos. São Paulo: UNESPUNICAMP-PUC-SP, Mestrado em Relações Internacionais, 2011.

MEDEIROS, Marcelo A., VILLA, Rafael. D. et al. (Org.). Clássicos das Relações Internacionais. São Paulo: Hucitec, 2010.

MINC, Alain. A nova Idade Média. São Paulo: $\quad 1994$.

MORAES, Antonio C. R. Geografia: pequena história crítica. São Paulo: Hicitec, 1987.

MORIN, Edgar. Os sete saberes necessários à Educação do Futuro. 10a . ed. São Paulo: UNESCO/Cortez,
Educação e Complexidades: os sete saberes e outros ensaios. $3^{a}$. ed. São Paulo: Cortez, 2005a.

MORGENTHAU, Hans. A política entre as nações: a luta pelo poder e pela a paz. Brasília: Ed. UnB, 2003.

NYE Jr., Joseph S. 0 paradoxo do poder americano. São Paulo: UNESP, 2002.

ONU. Aliança de Civilizações: o Fórum do Rio de Janeiro. Brasília: Funag, 2011.

ORO, Ari P. \& STEIL, Carlo A.(Org.). Globalização e Religião. $2^{\underline{a}}$ ed. Petrópolis: $\quad 1999$.

PIERUCCI, Antonio Flávio. 0 Desencantamento do Mundo. Todos os passos do conceito em Max Weber. São Paulo: $\quad$ Ed. 2003.

PIERUCCI, Flávio \& PRANDI, Reginaldo. A realidade social das religiões no Brasil. São Paulo: Hucitec, 1996.

RAFFESTIN, Claude. Por uma Geografia do Poder. São Paulo: Ática, 1993.

RAMONET, Ignácio. Geopolítica do caos. Petrópolis: $\quad$ Vozes, 1998.

RESENDE, Erica S. A. Americanidade, Puritanismo e Política Externa: a (re)produção da ideologia puritana e a construção da identidade nacional nas práticas discursivas da política externa norte-americana. São Paulo: USP-FFLCH, Ciência Política. Tese Doutorado, 2009, p.334. 
RIBEIRO, Edgard T. Diplomacia Cultural seu papel na política externa brasileira. Brasília: $\quad$ Funag, 2011.

RIBEIRO, Wagner C. Ordem Ambiental Internacional. São Paulo: Contexto, 2001.

ROMANO, Roberto. "A Paz da Westfália (1648)”. IN: MAGNOLI, Demétrio (Org.). História da Paz. São Paulo: Contexto, 2008, pp. 69-92.

ROSENAU, James et al. (Org.) Governança sem governo - ordem e transformação na política mundial. Brasilia:UnB; São Paulo: Imprensa Oficial, 2000.

ROSENDAHL, Zeny. Espaço e Religião: uma abordagem geográfica. Rio de Janeiro: $\quad$ EdUERJ, 1996.

Primeira a obrigação, depois a devoção: Estratégias espaciais da Igreja Católica no Brasil de 1500 a 2005. Rio de Janeiro: EdUERJ, 2012.

ROSENDAHL, Z. \& Roberto L. CORRÊA. Introdução à Geografia Cultural. Rio de Janeiro: Bertrand Brasil, 2003.

Geografia Cultural: uma antologia, volume I. Rio de Janeiro: EdUERJ,

2012.

Geografia Cultural: uma antologia, volume II. Rio de Janeiro: EdUERJ, 2013.

SANTOS, Alberto P. Geopolítica das Igrejas e anarquia religiosa no Brasil por uma geoética do apoio mútuo. Tese de Doutorado. São Paulo: USP, FFLCHDepto. de Geografia, 2011.

Geoética e Relações Internacionais. Rio de Janeiro: Revista Geo UERJ, ano 14, no 24, 2ㅇ. Semestre 2012, pp.

479-508.

Introdução à Geografia das Religiões. São Paulo: Revista GEOUSP espaço e tempo, n ‥ 11, 2002, pp. 21-33.

SANTOS, Milton. Por uma Outra Globalização. 9a ed. Rio de Janeiro-São Paulo: Record, 2002.

SARAIVA, J. Flávio S. (Org.). História das Relações Internacionais Contemporâneas - da sociedade internacional do século XIX à era da globalização. 2ª . ed. São Paulo: Saraiva; Brasília: IBRI, 2008.

SARFATI, Gilberto. Teoria de Relações Internacionais. São Paulo: Saraiva, 2005.

VESENTINI, J. William. Nova Ordem, Imperialismo e Geopolítica Global. Campinas: 2003.

Novas Geopolíticas. São Paulo: Contexto, 2000.

WALTZ, Kenneth N. O Homem, o Estado e a Guerra. São Paulo: Martins Fontes, 2004.

WEBER, Max. A Ética Protestante e o Espírito do Capitalismo. São Paulo: Martin Claret, 2004.

Economia e Sociedade. Brasília: UNB, 1984. 
GEOGRAPHY, TOURISM, RELIGION AND INTERNATIONAL RELATIONS: AN INTRODUCTION TO THE THEORETICAL INTERFACES.

ABSTRACT: THIS PAPER LAUNCHES AN INTRODUCTORY DIALOGUE ABOUT THEORETICAL INTERFACES BETWEEN GEOGRAPHY, TOURISM, RELIGION AND INTERNATIONAL RELATIONS. CONSIDERING GEOGRAPHY THE STARTING POINT FOR THIS DISCUSSION, OUR AIM IS TO SHOW BRIEFLY THAT TOURISM AND RELIGION ARE CONSTITUTED AS THEMES THAT INTERCONNECT WITH INTERNATIONAL RELATIONS: TOURISM AS AN INSTRUMENT OF CULTURAL DIPLOMACY OR SOFT POWER WITHIN THE GLOBALIZATION CONTEXT, WITH THE ADVANCES OF TECHNOLOGIES OF COMMUNICATION TECHNOLOGY AND MEANS OF TRANSPORTATION IN THE "ACCELERATION OF TIME-SPACE COMPRESSION" PROCESS (HARVEY, 1993), AND RELIGION IN POST-COLD WAR SETTING, WITH THE RISE OF THE NEW GEOPOLITICS AND THE APPRECIATION OF CULTURES, CIVILIZATIONS AND ETHNIC-RELIGIOUS GROUPS AS AGENTS THAT INTERFERE IN THE POWER RELATIONS THROUGHOUT THE WORLD SPACE (VESENTINI, 2000). AN ATTEMPT IS ALSO MADE TO DEMONSTRATE THAT THE FOUR THEMES IN THIS PAPER TITLE RAISE RELEVANT POINTS COHERENTLY RELATED TO THEORETICAL REFLECTION THAT FAVOR THE RELATIONSHIP BETWEEN SPACE AND CULTURE.

KEYWORDS: GEOGRAPHY; TOURISM; RELIGION; INTERNATIONAL RELATIONS; CULTURE. 
GEOGRAFÍA, TURISMO, RELIGIÓN Y RELACIONES INTERNACIONALES: UMA INTRODUCCIÓN SOBRE LAS INTERFACES TEÓRICAS

RESUMEN: ESTE TRABAJO SE INICIA UN DIÁLOGO INTRODUCTORIO SOBRE INTERFACES ENTRE GEOGRAFÍA, TURISMO, RELIGIÓN Y RELACIONES INTERNACIONALES. TENIENDO EN CUENTA LA GEOGRAFÍA COMO PUNTO DE PARTIDA PARA ESTA DISCUSIÓN, NUESTRO OBJETIVO ES MOSTRAR BREVEMENTE QUE EL TURISMO Y LA RELIGIÓN SON TEMAS ENTRELAZADOS COMO LAS RELACIONES INTERNACIONALES: EL TURISMO EN EL CONTEXTO DE LA GLOBALIZACIÓN, CON EL AVANCE DE LAS TECNOLOGÍAS DE LA COMUNICACIÓN Y LA LOS MEDIOS DE TRANSPORTE EN EL PROCESO DE "ACELERACIÓN DE LA COMPRESIÓN DEL TIEMPO Y EL ESPACIO" (HARVEY, 1993) Y LA RELIGIÓN EN EL CONTEXTO DE LA POST-GUERRA FRÍA ASCENSO GEOPOLÍTICO DE LA NUEVA CON LA APRECIACIÓN DE LAS CULTURAS, LAS CIVILIZACIONES Y LOS GRUPOS ÉTNICOS Y RELIGIOSOS, ACTORES QUE INTERFIEREN EN LAS RELACIONES DE PODER EN EL ESPACIO UNIVERSAL (VESENTINI, 2000). BUSCA TAMBIÉN ESTÁ MOSTRANDO QUE LOS CUATRO TEMAS DEL TÍTULO DE ESTE TRABAJO PLANTEAN LA REFLEXIÓN TEÓRICA RELEVANTE QUE HACE HINCAPIÉ EN LA RELACIÓN ENTRE LAS CONGRUENCIAS ESPACIO Y CULTURA.

PALABRAS CLAVE: GEOGRAFÍA, TURISMO, RELIGIÓN, RELACIONES INTERNACIONALES, CULTURA. 